\title{
CROSS-BREEDING FINNISH SHEEP WITH SCHWARTZKOPF RAMS.
}

\author{
Viljo Vainikainen. \\ Zootechnical Institution University, Helsinki.
}

Received 13. V. 1946.

During early autumn 1940 two German sheepbreeding specialists, Johannes von Gumppenberg and Felix Lilienthal, visited Finland on their own initiative for getting aquainted with Finnish sheep-breeding. According to their determination the Finnish common variety of sheep is well adapted for the circumstances prevailing in Finland and extremely prolific, but very small in size and a weak producer of wool. For improving the latter qualities they suggested tests be made by cross-breeding the Finnish sheep with the schwartzkopf-breed, which they claimed was a modest wool-meat breed, well adapted even to the Finnish circumstances. Resulting of earlier experiences, according to which foreign breeds of sheep have not owing to their low proliferation and the hard Finnish conditions permanently succeeded, this plan caused many doubts. Despite this three schwartzkopf-rams, born 1939 in East-Prussia, were imported to Finland in October 1940, with which the leadership of the German sheep-breeding hoped Finnish sheep would be cross-bred. When the rams in November were freed from veterinary quarantine, ram No. 9119 was situated on the Saari estate in Mäntsälä, No. 4482 on the estate owned by the Kerava Youth Penitentiary in Kerava and ram No. 8858 on the Pasture Experiment Station of Selkee in Mouhijärvi. Most of the ewes on the mentioned estates were, on the arrival of the mentioned rams, already pregnant so that in autumn 1940 only some few ewes could be served by the experimentary rams in question.

Owing to the unadvantageous results received in Finland from experiments with foreign breeds, a special agreement was made with the above mentioned farms, according to which they were unallowed to sell any animal born from cross-breeding with schwartzkopf rams, which could be used for further breeding. This measure was to prevent the too early spreading of cross-bred animals into the rural districts and thus protect the local breed as a pure one. Now after the conclusion of experiments, it must be with satisfaction established that this precaution proved a success. 
Regarding the breedcharacteristics of the Finnish sheep, the following may be mentioned. Head covered with guard-hair, alive eyes, erect ears of fair length. The legs are bony, thin and covered with guard-hair. The tail consists of $10-12$ vertebrae, is thick at stem, narrowing towards the tip and short. The breast is often fairly narrow and puckered, back sway, the back-part of the body weak and poor in muscles.

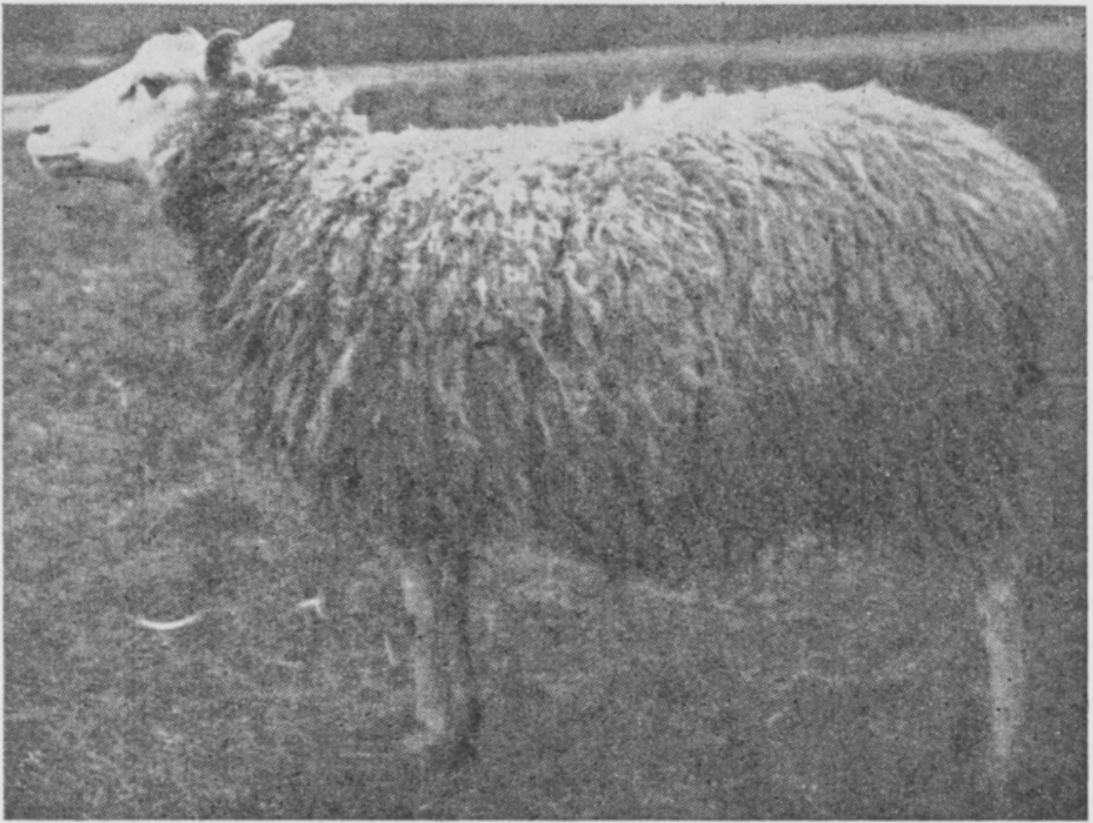

Picture I. Finnish ewe. Coarseness of wool $52 \mathrm{~S}$ (household-wool).

Loss in slaughtering is considerably great. To mention some of the advantageous characteristics of the Finnish sheep, its ability to accomodate itself, its small needs, excellent proliferation and quick growth.

The wool is of a mixed composition, but there are individuals with either only

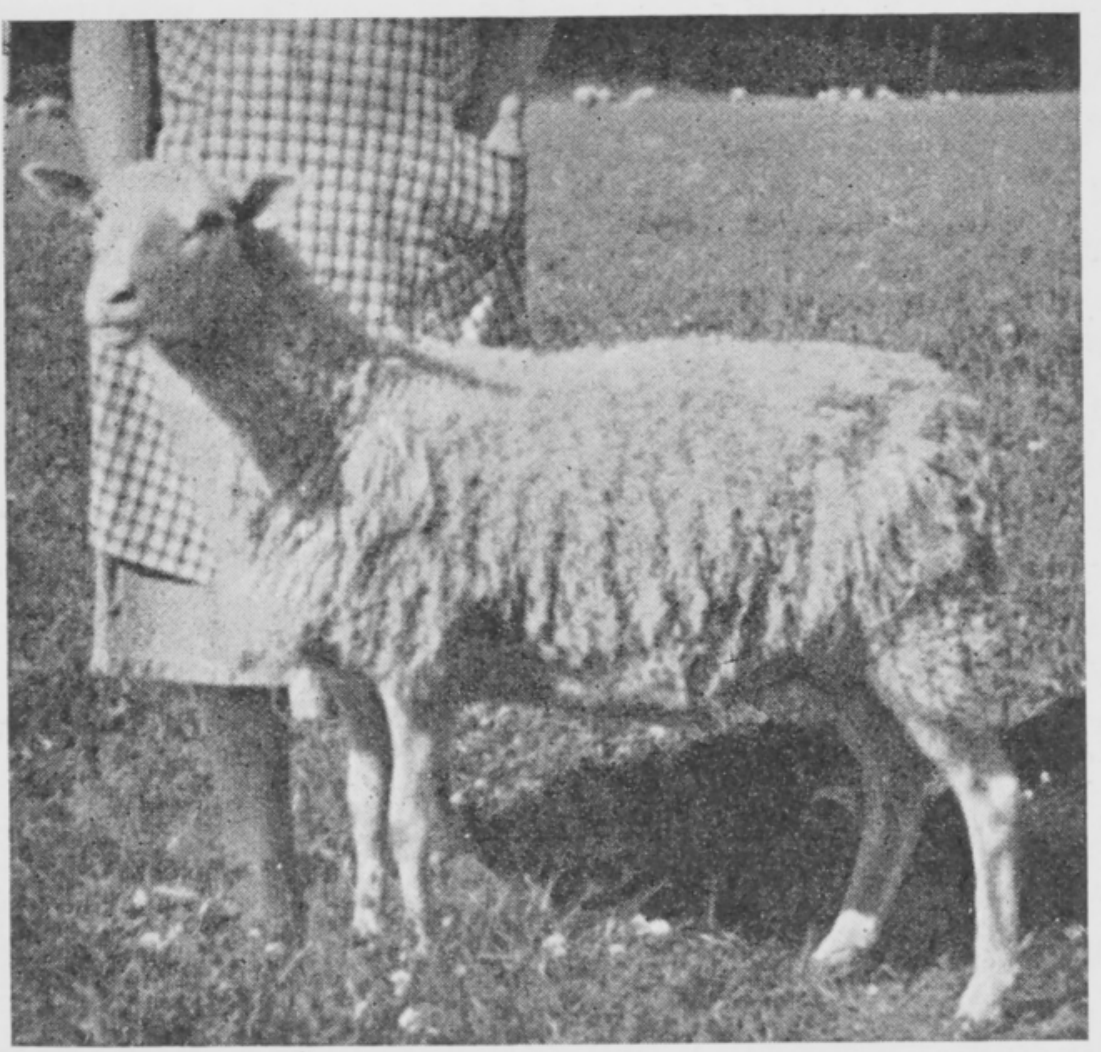

Picture 2. Finnish ewe with wool adapted for textile-purposes. underwool or only guardhair. The average coarseness of the wool is $50-54$ English units. The average weight of ewes measured in centres of breeding during 1943 - 45 was for over 2-year olds 50.9 kilogramms, and the average proliferation during the same period 2.49 lambs per ewe and per each lambing.

The schwartzkopffleisch sheep is a member of the wool-meat breed, which has been developed through cross-breeding from English breeds such as Oxfordown,Hampshire and Suffolk breeds (GoLF (5) and Will-Hannover 


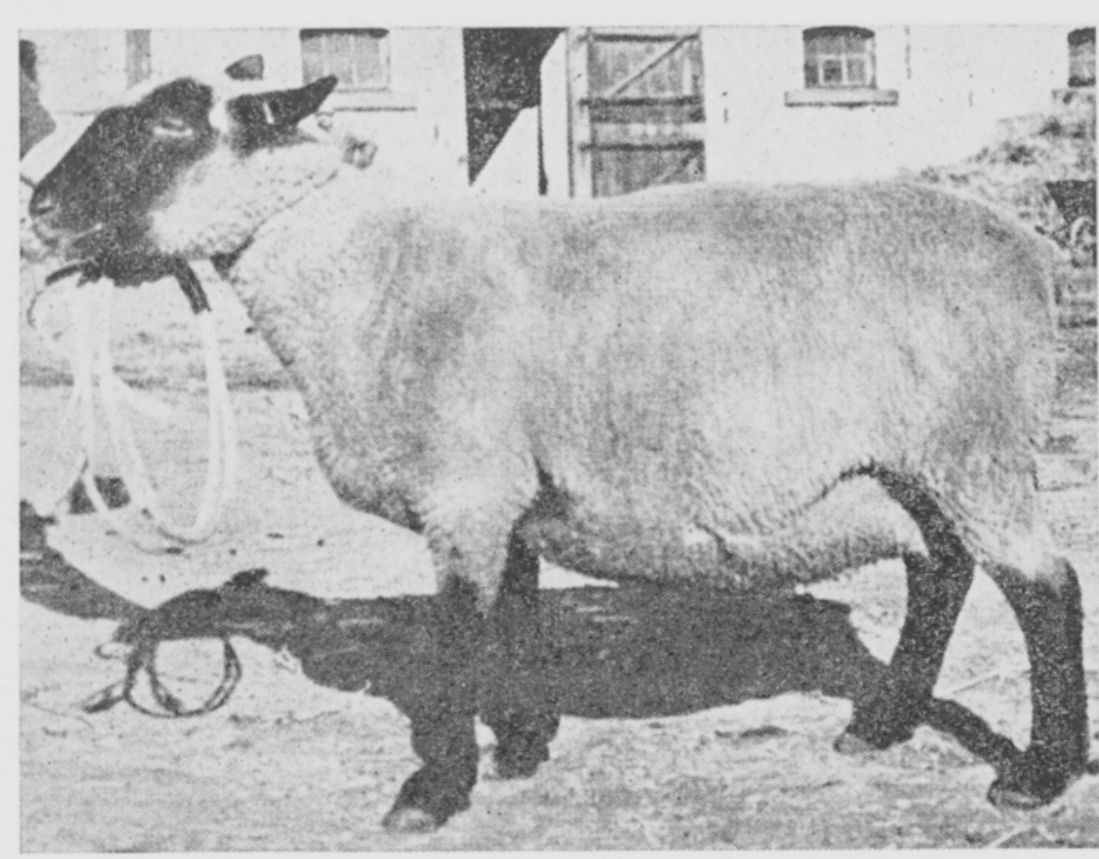

Picture 3. Schwarzkopf ewe.
(12). The black-headsheep is fairly undemanding and enduring. Its colour is white, except for the head and legs which are black. The lambs show some dark patches on birth, which however vanish later w ith the age. The head is bare of wool, except for the forehead and cheeks. The tail is long, thick and limply hanging. The build of body of the black-head sheep is strong and muscular. The breast is deep and broad and the back-

part of the body strong. According to measurements made in basic flocks, which probably answer the Finnish breeding centers, during two successive years, 1936 and 1937, the average weight of 8905 ewes was 61.1 kilogrammes, the average proliferation 1.20 lambs and the corresponding production of wool 3,28 kilogrammes per sheep. The loss in washing of the black-head sheeps wool is, according to German information, about $50 \%$, as it again correspondingly regarding wool from the common Finnish sheep is only $35 \%$, and thus as pure wool the difference in wool-production of these two breeds is considerably reduced.

\section{Cross-breeding with sheep in other countries.}

Owing to the recent war there has been no information available of the possible experiments undertaken in either England or the United States, so that this treatise can only deal with Anglo-American litterature received in Finland before 1939. TÄNZER (9), in his research regarding the hereditary qualities of the thickness of wool, has established, that mixed wool dominates over both even and fine wool. According to corresponding experiments made by Davenport and Ritzman (4), the results are dependant on the breeds used in cross-breeding. Thus $\mathrm{F}_{1}$-generation resulting from crossing Hampshire and Rambouillet breed shows coarse wool as dominating. On the other hand in cross-breeding between Southdown and Rambouillet breeds and between the latter and the Oxford breed, the thickness of woolhairs has proven intermidiarily hereditary. The same result has also been reached by Burnes (2), Darlow (3), Kronacher and Schäper (7) and Scholz (8). In experiments carried out by Ulmansky (10), the average coarseness of wool in $F_{1}$ generation offsprings was in some cases nearer that of the fathers, and in some cases nearer that of the mothers, in addition to which in some cross-breedings the 
coarseness of wool in $\mathrm{F}_{1}$-generation was intermediary. In cross-breeding experiments carried out by KIRSCH (6) between Merino and East Friesian common sheep, the fine hair of the former proved to be dominant in $\mathrm{F}_{1}$-generation. In experiments carried out by the author (1946), in which common Finnish sheep where cross-bred with karakul rams, the average coarseness of wool in $\mathrm{F}_{1}$-generation offsprings was very near the corresponding numeral value of that of the mothers. In judging the results of the mentioned tests, it must be remembered that the thickness of wool in different individuals can greatly vary even inside the same breed. If small numbers of material are used in the tests, those individuals which greatly differ from the average can considerably influence the numeral value fixed to represent the average thickness of hair in the breed, and thus also the results reached from crossbreeding. When judging the latter, it is therefore important to note the distribution of thickness of wool in the original cross-breeding material $(\delta)$.

There has been no information regarding experiments with quantity of wool at the authors disposal. The hereditary qualities of the denseness of wool are mentioned by DarLow. According to him denseness of wool proved dominant in the $\mathrm{F}_{1}$-generation resulting from cross-breeding the Dorset and Shropshire breeds. In cross-breeding experiments, Hampshire $\times$ Rambouillet, carried out by Burnes, the denseness of wool was inherited intermediarily.

According to Wriedt (13) and Kronacher those genes influencing the size of body are inherited intermediarily.

\section{Own Experiments.}

The following summarised account of material used in experiments directed by the author, has been collected by the Association for Sheep- and Goat Breeding. It is to be regretted that the material owing already to the shortness of the experimentary period, has remained small especially regarding the $\mathrm{F}_{2}$-generation. For the same reason there has been no time to carry out any return-crossings in the experiments. After the author and officials of the Association had been called to military service, the experiments could not be carried out to the planned extent. Similarly the samples taken and notes made have either been losed, or remained totally unmade, which naturally has diminished the fitness for use of the material. Despite the mentioned deficiencies, however, the author has been willing to carry out the investigation in the extent allowed by the material at his disposal. Publishing of results is made justifiable by the fact, that the experiments have now been concluded, as the black-head rams being unused to the Finnish conditions have died. On the other hand it must be established, that the sheep-breeders interest in the question has discontinued, as after returning of normal conditions Finland has re-established import of cheap foreign wool, with which the home-produced Finnish wool is unable to compete owing to higher production-cost. Owing to this the chief interest of Finnish sheep-breeding is at present centered around production of pelts, for which purpose the Finnish sheep with its curly pelt and exceptional lustre ought to be well adapted. 
The thickness of wool has in the investigation been measured using a ccularymicrometre attached on a Leitz-Wetzlar microscope with the exactness of $1 \mu$. Wool-samples have been washed in ether and after drying 100 hairs have been measured using glycerol as the covering substance. The samples have been taken from the shoulders of the sheep.

In addition to microscopic measurements, the English units regarding coarseness of hair have been established by fingering from the shoulders, cross-back and thigh of live sheep. All estimations have been carried out by the same skilled person, whose routine work includes the same task.

Wool produced by sheep included in the experimentary material has been weighed in both autumn and spring during two successive years and the average annual production of each individual has been established on basis of the received results.

The live weight of sheep has been established in similar manner as the wool production.

The loss in washing of the wool has been established by taking a sample from the shoulders, cross-back and thigh of every sheep, from which 10 grammes has been weighed for washing. The wool has been washed using German made Igopal washingstuff, commonly used by wool-manufacturers. The solution for washing was prepared by adding 4 grammes of Igopal to 1 litre of luke water. The washing procedure took half an hour, after which the rinsing was first done in luke warm, and then in cold water. The samples were dried in a heat cupboard with $50^{\circ} \mathrm{C}$ for 24 hours. After this the washed samples remained for 48 hours in room-temperature, and thus the final weight as also the original weight were established regarding air-dry wool.

The colour has been judged directly after birth of the lamb. Those characteristics of animals resulting from cross-breeding, the inheritance of which has not been able to be clarified to the same extent as those above-mentioned, shall be explained in the text.

Results.

As mentioned already above the coarseness of wool-hairs has been established both microscopically and feeling with hand in this research. Results received using the former method are indicated by the graphical curve in table 1. below.

The peaks of curves representing the coarseness of shoulder-wool in those Finnish ewes used for cross-breeding are steeper than those of the other curves in the table, except for the $\mathrm{F}_{2}$-generation. The average coarseness of shoulder-wool in Finnish ewes has been $23.74 \pm 3.13 \mu(\sigma=5.18)$, it in the original schwartzkopf rams having been $36.83 \pm 1.92 \mu(\sigma=3.33)$. Established separately in all three above-mentioned rams it has been $32.98 \pm 0.82 \mu, 38.36 \pm 0.70 \mu$ and $38.90 \pm$ $0.71 \mu$. The difference between the extremeties $5.92 \pm 1.10 \mu$ is despite its mathematical certainty considerably small, and thus the pure bred rams used in crossbreeding were very similar regarding their coarseness of wool. 
The wool-samples for microscopic inspection have been taken from the 32 offsprings of $\mathrm{F}_{1}$-generation, and their average has been 26.86 $\pm 0.11 \mu(\sigma=5.96)$. According to this the fine wool of the mother has proved dominant, although the dominating has been imperfect. The result is similar to that received by the author in experimenting with karakul cross-breeding (VAINIKAINEN 1946).

The wool of only 8 individuals of the $\mathrm{F}_{2}$-generation has been available for microscopic examination, and the coarseness has to an average been $21.28 \pm 0.17 \mu(\sigma=4,88)$. Although the judgement must be influenced by the small amount of individuals in $\mathrm{F}_{2}$ generation, it is interesting to notice that according to the

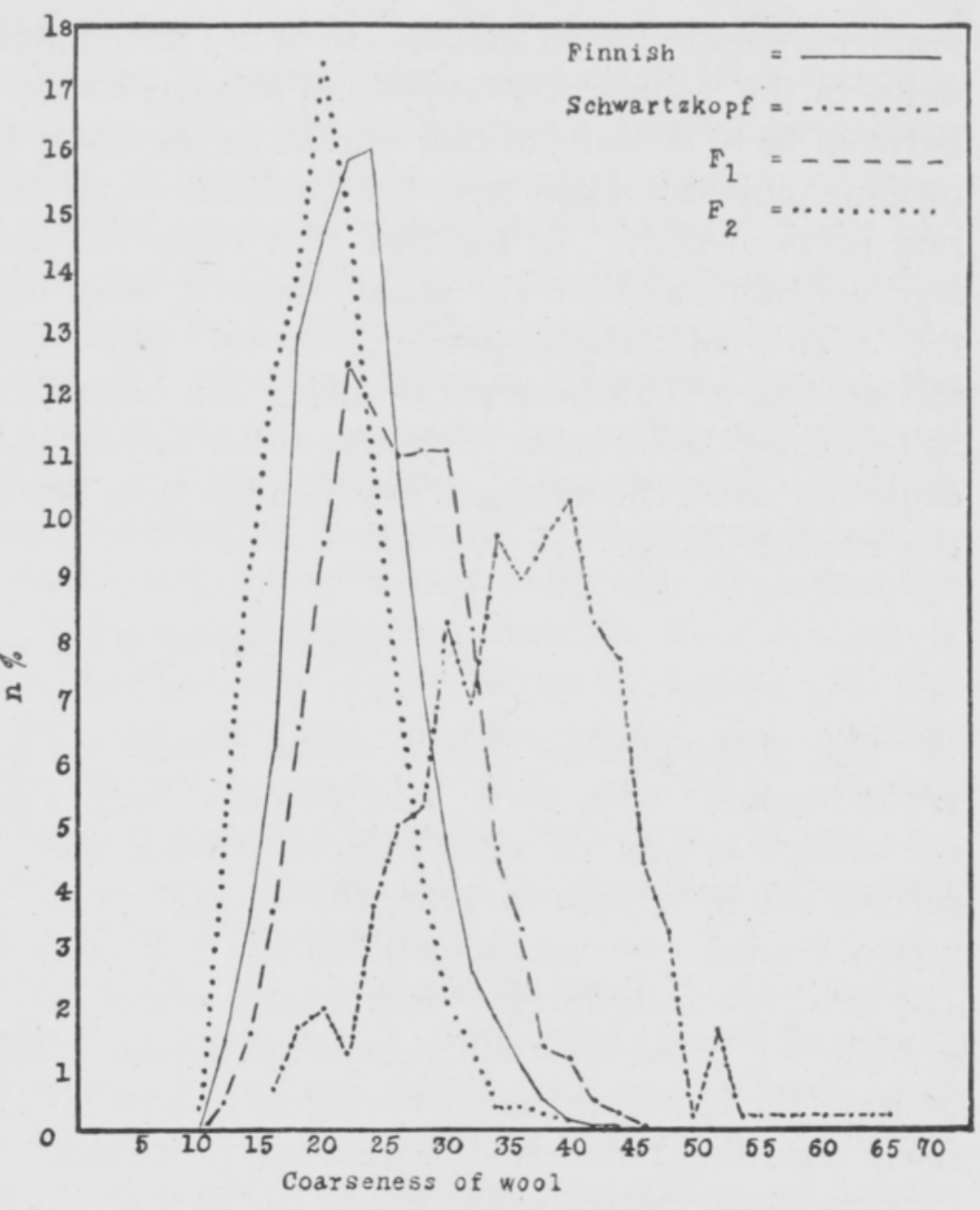

Table I. Coarseness of hair taken from shoulder. graphic curve pictured in table 1 representing the coarseness of hair in $\mathrm{F}_{2}$-generation, has been the steepest.

According to earlier mentioned information, the coarseness of wool has also been established by feeling with hand. The judgement has been made by the same person on basis of the shoulder, cross-back and thign wool in live sheep. Thus specified the wool in the mentioned parts of the body in the Finnish ewe and repeated in the mentioned order has been to an average 61-59-56 English units of coarseness (5), it in the pure blackhead rams used in breeding having been $40-40-$ 38 (5). The examined material has included numerous ewes, whose coarseness of wool in all the mentioned parts has been of the same class of coarseness. Even the wool of offsprings of such mothers uniform wool has in $\mathrm{F}_{1}$-generation varied in the difterent parts of the body to an average less than that of the offsprings of other mothers. The average coarseness of shoulder-, cross-back and thigh-wool in $\mathrm{F}_{1^{-}}$ generation offsprings has been $56-54-50 \mathrm{~S}$. All this judgement indicates that the fine wool of the Finnish sheep has been incompletely dominating over the coarse wool of the schwartzkopfs.

Like already previously established $\mathrm{F}_{2}$-generation includes individuals with finer hair than that of the parents. Thus the shoulder-wool in best individuals has been 80 English units of coarseness against 60 units in the most fine-woolled 
mothers. Coarseness of shoulder-wool has in the mothers varied between 50 and 60 units, in the fathers between 48 and 58 units and in the offsprings of $\mathrm{F}_{2}$-generation between 58 to 80 units of coarseness. In the latter as also in the mothers, the wool in some individuals can have been uniform as to the average diametre in the different parts of body. In the case that there has been a difference noticeable, the shoulder-hair has been the finest, then the wool on the cross-back and after that the thigh-wool. The appearance of very fine-woolled individuals may possibly feel surprising. This however probably can be explained that the black-head breed being a cross-bred results of various other breeds, its genotype includes genes which cause fine wool, the influence of which has been brought forth even in crossbreeding the Finnish sheep.

\section{Quantity of Wool.}

One of the greatest defects of the Finnish sheep is its fairly sparse wool, there are individuals with even bald patches under their stomach and owing to this the annual output of wool remains considerably. low. According to researches carried out by myself in 1938, the average production of wool shown by a fullgrown Finnish ewe was something like 2 kilogrammes unwashed wool annually. The total naturally includes individuals, whose annual production of wool can rise as high as 6 kilos. Such individuals are, however, uncommon, but in any case they indicate the important fact proving as to how far at least breeding of the Finnish sheep regarding production of wool can be carried. As the country in normal times imports cheap foreign wool, and as the own production of wool owing to the short pasture-period becomes at least to that extent expensive that it is not able to compete with the prices of imported wool, the Finnish breeders have shown practically no interest in developing the quantity and quality of wool in the Finnish sheep. It seems obvious, that with returning of normal conditions the chief interest will continuously be concentrated around meat-production, for which the Finnish sheep because of its great proliferation is economically extremely well adapted. As the Finnish sheep normally has a beautifully lustrous and curly pelt it is to be hoped, that these economical qualifications will be seriously considered by the Finnish sheep breeders and also purposefully developed.

In the examined material 51 Finnish ewes have during two successive years produced to an average $1.900 \pm 0.04 \mathrm{kgs}$ of wool. The individual production figures have greatly differed. Thus the smallest two-year production has been $1.350 \mathrm{~kg}$, during which time the best individual animal included in the experimentary material has produced $2.610 \mathrm{~kg}$. Except for hereditary qualities, the weak wool-production of Finnish sheep is also due to some outside factors. In this case, especially regarding the Finnish sheep, too mearge and monotonous food must be mentioned. One of the unadvantageous factors would also be a too great production of lambs. As the Finnish ewe can give birth to as many as 8 lambs, it can, but also regarding a smaller number of lambs, during gravity suffer from hunger, owing to which the wool can start coming off by itself, and the annual crop of wool to be shorn remains small 
because of this. The latter can also be caused by the mother simultaneously having several lambs, which, when the mother is laying down, jump on its back and thus cause the wool to come off in great tufts. The author has in another connection discussed the effect of the number of lambs on the annual production of wool. The material included in these calculations totalled 405 ewes who combinedly had 2027 lambs. The material was collected from such flocks, in which the feeding has been sufficient, and thus the shortage of food had no effect on the wool production. All years available have been recorded regarding every ewe, except however, the first and last lambing. The correlation received between the number of lambs and quantity of wool was $r=-0.205 \pm 0.021$. Despite the mentioned correlation multiplicand (correlation coefficient) is small to its numeral value, it is mathematically certain, and thus it can be established that with the number of lambs increasing the quantity of wool decreases. The small woolproduction of the Finnish sheep is also influenced by its smallish size. In the material collected by the author 178 ewes were weighed in autumn and spring during three successive years, their average weight being $47 \mathrm{~kg}$. The extreme variation was between 35 and $70 \mathrm{~kg}$. The correlation calculated from the material in question between the live weight and production of wool was $r=+0.289 \pm 0.07$. According to this the wool-production of the Finnish sheep can be increased by developing its size.

As previously explained the schwartzkopf-rams mentioned in this treatise were originally imported to Finland with the vie $x$ of advancing the production of wool. The rams in question produced during two successive years an average of $3.975 \mathrm{~kg}$ (ram No. 9119), $5.300 \mathrm{~kg}$ (No. 8858) and $6.050 \mathrm{~kg}$ (No. 4482). Although the difference between the extremeties has been rather great, the production despite this must be considered very high in comparison with the corresponding productions of the Finnish sheep.

Table 2 indicates results in $\mathrm{F}_{1}$-generation, in which the offsprings of the ram with the lowest production (No. 9119) have been marked with a line (-), those of ram No. 8858 with a cross $(+)$ and those of ram No. 4482 with a dot (. ).

The table includes the average production of wool of 47 Finnish ewes and their 51 offsprings during two successive years. The quantity of wool in Finnish ewes used for cross-breeding has varied somewhat more that that of the $\mathrm{F}_{1}$-generation offsprings. If the individual which has produced $4.125 \mathrm{~kg}$ is excluded from the comparison, very little difference can be noticed in the variations. The average wool production of those Finnish ewes served with the ram reaching the production of $3.975 \mathrm{~kg}$ during two successive years, for the corresponding period has been $1.908 \pm 0.05(\sigma=0.27)$ and that of the cross-bred offsprings correspondingly $2.446 \pm 0.06 \mathrm{~kg}(\sigma=0.31)$. The average production of wool of those ewes served with the ram second in wool-production, has been $1.864 \pm 0.07 \mathrm{~kg}$ and that of their offsprings $2.273 \pm 0.12 \mathrm{~kg}$; wool-production average of Finnish ewes served with the best ram has been $2.100 \pm 0.31 \mathrm{~kg}$ and that of their offsprings, which have only numbered 3 , correspondingly $2.833 \pm 0.18 \mathrm{~kg}$. Considering the material as a whole, the average production of wool of those ewes used in cross-breeding can be calculated as $1.900 \pm 0.04 \mathrm{~kg}(\sigma=0.32)$, that of the pure black-head rams $5.100 \pm$ 
Table 2. Production of wool of Finnish ewes and $F_{1}$-generation offsprings during two successive years to an average $\mathrm{kg}$.

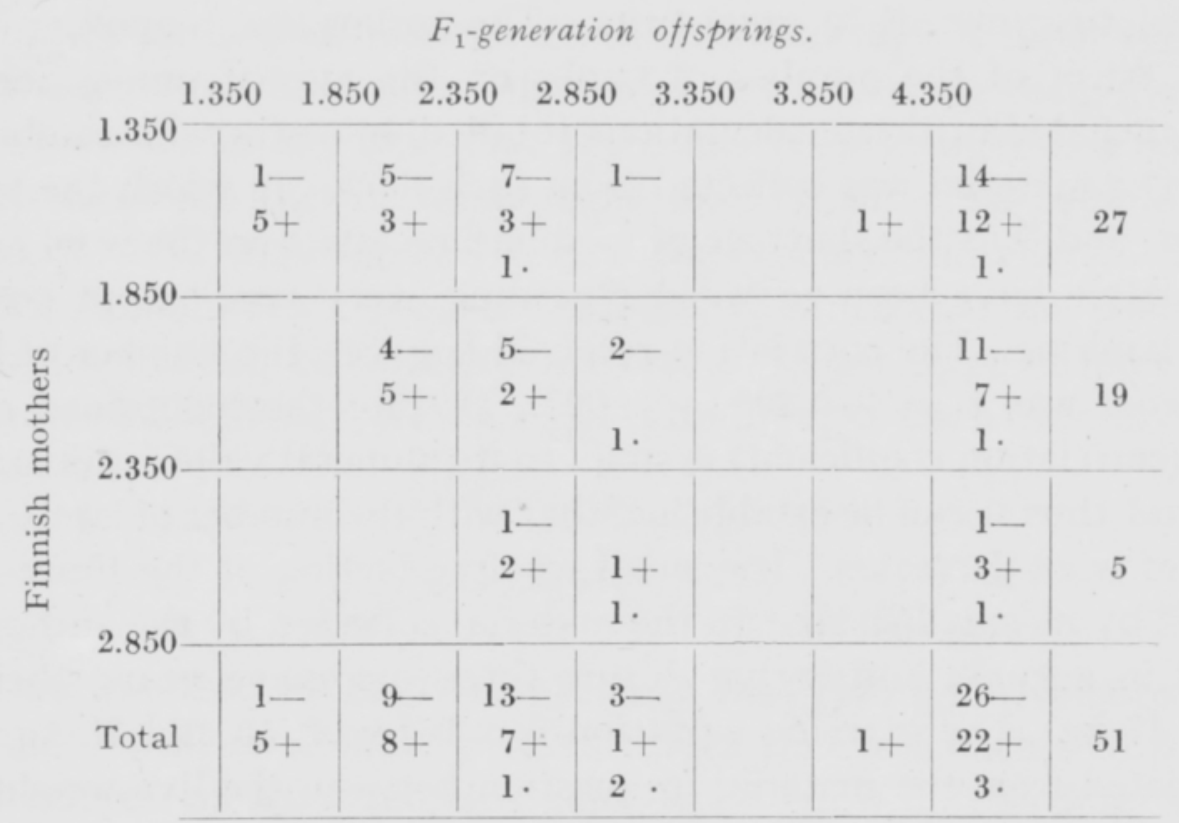

$0.64 \mathrm{~kg}(\sigma=1,11)$, and that of their cross-bred offsprings as $2.394 \pm 0.06 \mathrm{~kg}$ $(\delta=0.44)$. According to this it can be stated, that the low production of wool of the Finnish sheep has been incompletely dominating over the high production of the black-head breed.

There has been no occasion to examine the wool-production of $\mathrm{F}_{2}$-generation offsprings in an extent to have any meaning for drawing practical conclusions. It can, however, be assumed that the sheep's production of wool is dependant, judging from even only the distribution recorded in Finnish material, on at least 3-4 homomeric genes.

Weight.

The live weight of rams used in the cross-breeding experiments has been $85.0 \mathrm{~kg}$ (ram No. 8858), $92 \mathrm{~kg}$ (ram No. 4482) and $92,5 \mathrm{~kg}$ (ram No. 9119). The average weight of Finnish ewes served with the last mentioned ram, the one with the smallest production of wool, has during two successive years varied in different individuals between 39.5 and $61 \mathrm{~kg}(\delta=5.54)$, the àctual average being $47.2 \pm$ $1.11 \mathrm{~kg}$. The extremeties of weight in their $\mathrm{F}_{1}$-generation offsprings have been 39 and $61.5 \mathrm{~kg}(\delta=6.52)$ and the actual average $50.0 \pm 1.30 \mathrm{~kg}$. The weight of those ewes served by the lightest ram, which produced to an average $5.300 \mathrm{~kg}$ wool, has varied between 39 and $61 \mathrm{kgs}(\delta=5.80)$, the average being $48.5 \pm 1.24 \mathrm{~kg}$ and that of the cross-bred offsprings correspondingly $35-72 \mathrm{~kg}(\sigma=7.72)$, the average weight being $45.1 \pm 1.65 \mathrm{~kg}$. The live weights of the ewes served with the third ram, weighing $92 \mathrm{~kg}$, which have numbered three have varied from 48 to 58 $\mathrm{kgs}$, the average being $55.0 \pm 3.06 \mathrm{~kg}$, the corresponding numeral values of their 
$\mathrm{F}_{1}$-generation offsprings being $53-62$ and $59.0 \pm 3.06 \mathrm{~kg}$. The average weight of all Finnish ewes icluded in the experimentary material has been $48.20 \pm 0.82$ $\mathrm{kg}$, and that of the $\mathrm{F}_{1}$-generation offsprings $48.36 \pm 1.10 \mathrm{~kg}$. The average weight of the rams used in cross-breeding has been $90.34 \pm 2.68 \mathrm{~kg}$.

Judging on basis of the author's material the small live weight of the Finnish sheep has been dominating over the greater weight of the black-head breed. The average weights of Finnish ewes and their $\mathrm{F}_{1}$-generation offsprings are similar to a supprising extent. It possibly can be considered, that owing to weak feeding the $\mathrm{F}_{1}$-generation individuals have had no chance to develop in accordance with their hereditary qualities. Regarding this possibility, it must however be stated, that the sheep included in the experimentary material have only been distributed to three farms, on which the feeding of sheep has been stronger and more purposefull than to the average in Finland.

Owing to numerous cases of illnes and resulting deaths, there has not been sufficient information regarding $\mathrm{F}_{2}$-generation offsprings available for making an analysis.

\section{Wool's loss in washing.}

The wool's loss in washing, which has been calculated according to the previously explained method, has to an average been in the black-head rams used for crossbreeding $28.0 \pm 7.04 \%$. An average of $23.0 \pm 1.50 \%$ has been losed from the wool of Finnish ewes after washing, the extreme limits varying between 14.6 and $35.6 \%$. The average loss after washing in wool of $\mathrm{F}_{1}$-generation offsprings has been $23.7 \pm 1.29 \%$, varying between 14.7 and $36.5 \%$. As far as conclusions can be drawn on basis of these results, as it has been received by comparing the washingloss of only 21 mother-offspring pairs, it seems like the low washing-loss would be dominating.

Making comparisons between the average washing-losses of Finnish ewes and their $\mathrm{F}_{1}$-generation offsprings a striking similarity is noticeable, as the difference between the averages $-0.7 \pm 1.98$ is so small it can not even be considered mathematically certain. It could possibly be considered, that the similarity in washinglosses simply is due to the fact that the compared sheep have been living under same outside conditions and have been equally fed. As according to experiments made otherwere with Finnish sheep its washing-loss is considerably smaller than in foreign breeds, also this can be considerad dependant on outside factors. It could be thought, that the wool of a Finnish sheep on a poorer diet does not collect so much fat, which disappears in washing, in its wool as the better fed foreign breeds. The differences in washing-losses is probably to be explained thus, but not totally. Examining the $\mathrm{F}_{2}$-generation resulting from cross-breeding, its especially extensive distribution catches the eye. Thus the lowest washing-loss has only been $13.4 \%$, but the greatest as high as $42.1 \%$, the average rising to $28.8 \pm 3.59 \%$. As the $\mathrm{F}_{2}$-generation individuals in question have existed in exactly the same conditions as the Finnish ewes and $\mathrm{F}_{1}$-generation offsprings it does not seem probable, that the 
washing-loss would be influenced by outside factors alone. Despite the fact, that $\mathrm{F}_{2}$-generation has only included 8 offsprings to be examined, the author would be ready to believe, that the washing-loss of wool, i.e. formation of wool-fat, is also influenced by hereditary factors, which cause differences between the washinglosses in different breeds, and even individuals.

\section{Colour.}

The Finnish ewes used in cross-breeding have been white, which dominate the breed to about $80 \%$, the rest being grey and black, both latter numbering about equal. $\mathrm{F}_{1}$-generation offsprings of black-head rams and Finnish ewes included thirty coloured similarly as the father, i.e. head and legs black. Except these the offsprings included 6 individuals with head and legs of light grey colour. The colouring of the black-head breed has thus been incompletely dominating.

In the second cross-bred generation 8 individuals had a black head and black legs, 6 individuals a light-grey head and legs and two offsprings have been totally white like the Finnish mothers. The number of individuals in $\mathrm{F}_{2}$-generation has been too small to establish the number of genes influencing the colouring. It seems, however, obvious that the difference in colour between the Finnish sheep and the black-head breed is dependant on but one factor of colour. The light grey probably is a result of only the fact, that a part of the black hairs have later turned white, as according to observations made by the author, is customary with black Finnish sheep, thus forming sheep grey in colour.

In addition to the previous it can as a general impression be mentioned regarding the cross-bred animals, that the $\mathrm{F}_{1}$-generation lambs have as a rule been heavier than those of the common Finnish sheep. The build of cross-bred offsprings has generally been good, trunk long, back straight, hind-quarters broad although somewhat sloping and the tail long and drooping. Despite no exact numbers unfortunately can be given regarding production of lambs, it can however as a general impression be stated; that the cross-bred animals can be fully compared with the fecundity of Finnish ewes. As a noteworthy fact it must also be established, that in quite numerous cases the $\mathrm{F}_{1}$-generation offsprings had to be taught to suck, which regarding pure Finnish lambs had to be extremely rarely done. In addition it must be stated, that the cross-bred individuals seemed to get easily ill, Finnish lambs under the same conditions simultaneously remaining in the best of health. Although the build of Finnish sheep possibly could be improved by cross-breeding with the schwartzkopf breed, it size increased and its production of wool advanced, there seems no reason to continue these cross-breeding experiments even after returning of normal times, because of already only the great requirements of the schwartzkopf breed and owing to its weak ability to adapt itself to the Finnish conditions. Still the less reason, as the chief importance in future is to be centered around producing pelts for fur purposes.

The above mentioned is by no means to be understood that there would be no reason to increase the size of Finnish sheep and eliminate the weaknesses which 
still today so often appear in it. This must however be carried into effect through inbreeding at the same time putting special importance in the selection of breeding animals. To make good breeding animals more easily and quicker available the Association for Sheep and Goat Breeding has already established an own breedingram station, which has been furnished with the best ewes and rams available. In addition to purposeful breeding-selection also the care and feeding of sheep must simultaneously be rendered more effective, as this is the only method to decide the hereditary qualities and real value of the Finnish sheep.

\section{Final Conclusions.}

On basis of the examined, the following conclusions can be drawn:

1) The coarseness of wool in $F_{1}$-generation offsprings has been very near to the average coarseness of wool of the mothers.

2) The low wool-production of the Finnish sheep has been incompletely dominating over the quantity of wool in schwartzkopf sheep.

3) The low live-weight of the Finnish sheep has been dominating.

4) The small loss in washing characteristic to the Finnish sheep has been dominating.

5) The colouring of Schwartzkopfs has been incompletely dominating.

6) As to size and build the cross-bred animals have been better than pure Finnish lambs. Finnish ewes have, however, been more economical regarding their production of sheep. The cross-bred animals have been inclined to easily get ill. For this reason as also owing to the present channels of Finnish sheep breeding aimed at fur production, there seems no necessity to continue schwartzkopf-crossings. The characteristics of Finnish sheep must in the future be improved through purposeful inbreeding. Considering the great variation of characteristics in the Finnish sheep also this method will lead to results, however, only if the selection is carried out effectively and the outside factors advantageous for the development of the sheep.

Finally I want to thank the director of the Association for Sheep and Goat Breeding, agronome N. InkovaARA and the district breeding expert of the same association, agronome KERTTU TORIKKA for the help they have given me in collecting this material. I also have to express my thanks to the director of the Pasture Experiment Station Dr. A. Charpentier, to the manager of the Kerava Youth Penitentiary estate Mr. E. ERHo and to the manager of the Mäntsälä estate, agronome E. UUsitalo, who have taken care of the experimentary animals. 


\section{LITERATURE.}

(1) Abhandlungen des Landverbandes Westfälischer Schafzuchten. Bericht N:o 12, 1939.

(2) Burnes, R. H. Some phases of wool inheritance in $F_{1}$-generation. American Society of Animal Production Record of Proceedings of Animal Meeting. 1925.

(3) Darlow, A. E. Inheritance of characters in sheep. Oklahoma Agricultural Experiment Station. Bulletin 153, 1925.

(4) Davenport, C. B. and Ritzman, E. G. Some wool characters and their inheritance. New Hampshire Agricultural Experiment Station. Technical Bulletin 31, 1926.

(5) Golf, A. Zeitschrift für Schafzucht 1927, p. 234.

(6) KIrsch, W. Die Überführung des Mischwolle tragenden ostpreussischen Landschafes (genannt Skudde) in das schlichtwollige, veredelte württembergische Landschaf durch Verdrängungskreuzung. Zeitschrift für Tierzüchtung und Züchtungsbiologie N:o 8, 1927.

(7) Kronacher, C. und Schäper, W. Spaltend oder intermediär? Beitrag zum Entscheid über die Vererbungsform des Charakters »Wollfeinheit». Zeitschrift für Tierzüchtung und Züchtungsbiologie N:o 6, 1926.

(8) Scholz, W. Vererbungsstudien in einer Kreuzungsherde: Merinofleischschafe $\times$ Württemberger. 1927.

(9) Tänzer, E. Neuere Untersuchungen über die Vererbung beim Karakulschaf. Zeitschrift für Induktive Abstammungs- und Vererbungslehre Band 61, 1932.

(10) Ulmansky, S. Über Verbesserung und Vererbung der Wollfeinheit in der Cigojaherden der Herrschaft Rumana. Fortschritte der Landwirtschaft, 1926.

(11) Vainikainen, Viljo. Suomen karakulristeytyskokeista. 1946.

(12) Will-Hannover. Zeitschrift für Schafzucht 1927, p. 126.

(13) Wriedt, Chr. Ökonomiske husdyravel. 1926.

\section{SELOSTUS.}

\section{SUOMALAISEN LAMPAAN RISTEYTTÄMISESTÄ SCHWARTZKOPF-PÄSSEILLÅ.}

Suomalaisen lampaan vähäisen koon sekä heikon villantuotannon kohottamiseksi tuotettiin maahamme saksalaisten aloitteesta kolme schwartzkopf-pässiä, joilla koetarkoituksessa toivottiin risteytettävän suomalaisia uuhia. Kokeet aloitettiin v. 1940 ja sijoitettiin pässit Saaren kartanoon Măntsälään, Keravan Nuorisovankilan tilalle Keravalle ja Laidunkoetilalle Mouhijärvelle. Koetuloksista mainittakoon: Suomalaisen lampaan villan hienous sekä alhainen villamäärä ovat olleet epảtäydellisesti vallitsevat. Suomalaisen lampaan vähäinen elopaino ja pieni villan pesuhäviö ovat olleet vallitsevia ominaisuuksia. Schwartzkopf-pässien väritys on ollut epätäydellisesti vallitseva. Rakenteeltaan ja kooltaan ovar risteytyseläimet olleet paremmin kehittyneet kuin puhtaat suomalaiset karitsat. Karitsatuotannoltaan ovat suomalaiset emät kuitenkin olleet taloudellisemmat. Risteytyseläimet ovat sairastuneet paljon herkemmin kuin suomalaiset lampaat. Tämän vuoksi samoin kuin siitäkin syystä, että suomalaisen lampaan jalostus vastaisuudessa suuntautuu turkisominaisuuksien kehittämiseen ei schwartzkopf-risteytyksiä ole syytä jatkaa. Suomalaisen lampaan ominaisuuksia on karakulristeytyksiä mahdollisesti lukuunottamatta pyrittävä kehittämään yksinomaan määrätietoisella puhdassiitoksella. 